GEOLOGICAL SURVEY CIRCULAR 147

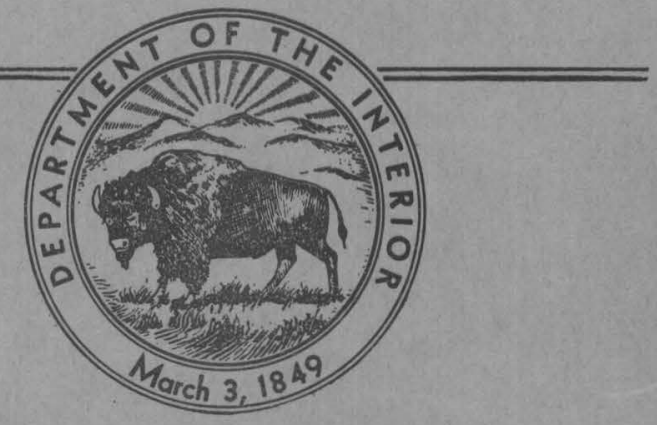

November 1951

\title{
GEQLOGY OF PROPOSED BLUE LAKE DAM SITE AND TUNNEL NEAR SITKA, ALASKA
}

\author{
By \\ William S. Twenhofel
}




\section{UNITED STATES DEPARTMENT OF THE INTERIOR}

Oscar L. Chapman, Secretary

GE OLOGICAL S URVEY

W. E. Wrather, Director

Washington, D. C.

Free on application to the Geological Survey, Washington 25, D. C. 


\title{
GEOLOGY OF PROPOSED BLUE LAKE DAM SITE AND TUNNEL NEAR SITKA, ALASKA
}

By

William S. Twenhofel

CONTENTS

Page

Fage

Introduction ............ 1

General Geology ............. 2

Origin of Blue Lake Basin ..... 2

Bedrock ........... 3

\section{ILLUSTRATIONS}

General Geology-Continued.

Dam Site.............. 3

Tunnel $\ldots \ldots \ldots \ldots$

\begin{abstract}
Fage

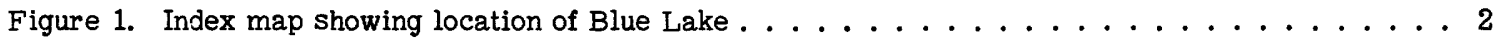

2. Blue Lake and vicinity, Baranof Island, Alaska ... . . . . . . . . . Inside back

cover
\end{abstract}

\section{INTRODUCTION}

In its plan to develop the pulp resources of Tongass National Forest, the U. S. Forest Service has included the Sitka area as one of the possible sites for a pulp mill, and it is proposed that hydroelectric power for the mill be developed from Blue Lake. At the request of the Regional Forester, U. S. Forest Service, Juneau, Alaska, the author examined the Blue Lake area May 23 to 26, 1950.

Blue Lake is a glacial lake 6 miles east of Sitka in Southeastern Alaska. (See fig. 1) It drains into Silver Bay, an arm of the Facific Ocean on the west side of Baranof Island, via the Medvetcha River, locally known as Sawmill Creek. The Medvetcha River, from Blue Lake to its mouth, is about 1.6 miles long and drops $200 \mathrm{ft}$ from Blue Lake to sea level.

The mouth of the Medvetcha River is reached by road from Sitka, a distance of about 6 miles. A good foot trail, $2 \frac{1}{2}$ miles long, leads from the end of the road to Blue Lake.

Maps of the area are as follows:

1. Chichagof-Baranof Island, Alaska map no. 8 , scale 1:250,000; published by U. S. Geological Survey.

2. Crawfish Inlet to Sitka, Baranof Island, chart no. 8255 , scale 1:40,000; published by U. S. Coast and Geodetic Survey.

3. Figure 2 of this report; Blue Lake and vicinity, modified from map prepared by Roy W. Johnson for Sitka Public Utilities.
Reports on the water power resources of Blue Lake are as follows:

1. Dort, J. C., Water powers of southeastern Alaska; Federal Fower Commission report, pp. 106-109, 1924.

2. Henshaw, F. F., Surface water supply of southeastern Alaska; U. S. Geological Survey Bull. 836-C, pp. 191-192, 155-157, 1933.

3. Water powers southeast Alaska; Federal Fower Commission - Forest Service report, pp. $97-98,1947$.

4. Irwin, W. H. , Blue Lake-Sitka area, unpublished Bureau of Reclamation report on geology of Blue Lake dam site.

5. Freliminary report on Blue Lake hydroelectric project near Sitka, Alaska, private report prepared by Harza Engineering Co., Chicago, Ill. , for the Alaska Industrial Corp., New York, N. Y. November $19,1948$.

Discharge records of the Medvetcha River have been maintained from September 1920 to January 1923, January 1928 to September 1942, and October 1945 to the present. Discharge records for the periods September 1920 to January 1923 and January 1928 to September 1930 are contained in the report by Henshaw. Discharge records for the periods September 1920 to January 1923 and January 1928 to September 1942 are contained in the Federal Fower Commission-Forest Service report. Discharge records for the period October 1945 to the present are not published but are available for inspection at the office of the Geological Survey in Juneau, Alaska. 
The Sitka Fublic Utilities has a license from the Federal Fower Commission to use the Medvetcha River as a power source.

According to the Federal Fower CommissionForest Service report (1947, p. 98):

"The first development was consiructed in. 1913. A flood in Cctober 1936 destroyed the diversion dam and part of the conduit. The present installation is as follows: A dam 12 feet high has a crest at the 71.1 foot elevation. The water is diverted through a conduit 1,427 feet long to a power house at the 16-foot elevation. "

In 1947 or 1948 a flood destroyed part of the conduit and damaged the left side of the dam. Since then the Sitka Fublic Utilities has purchased their power from the Alaska Native Service diesel plant on nearby Japonski Island and have made no attempt to repair either the dam or conduit. The power house with its machinery has been put in storage status.

About 1942 the Sitka Fublic Utilities began to construct a right-of -way for a conduit from the outlet of Blue Lake to its power house at tide level. This plan was abandoned in its early stages after a few hundred ft of rock right-of-way had been blasted along the right bank of the river just below the outlet of the lake.

\section{GENERAL GEOLOGY}

\section{Origin of Blue. Lake Basin}

Blue Lake occupies the western end of a large broad glacial valley that trends westward. The Medvetcha River occupies a deep V-shaped canyon whose walls rise abruptly 200 to $300 \mathrm{ft}$ above the stream. The valley is typical of the lower portions of many of the streams of southeastern Alaska in that the stream has excavated a deep canyon since the retreat of the glacial ice from the valley. Uplift of the land has caused the stream to down cut to its present base level. Once, since glacial times, the level of Blue Lake was about $400 \mathrm{ft}$ in altitude; since then the Medvetcha River has incised its way downward about $200 \mathrm{ft}$ and consequently lowered the level of Blue Lake to its present altitude.

The origin of Blue Lake is attributed to excavation by glacial action in the bedrock of the valley. In the unpublished Bureau of Reclamation report on the geology of Blue Lake dam site, by W. H. Irwin, two theories of origin for Blue Lake were proposed: That the lake and the valley it occupies is a graben or down-dropped block of the earth's crust; or that the lake was formed by the damming of the valley by glacial-deposited debris.

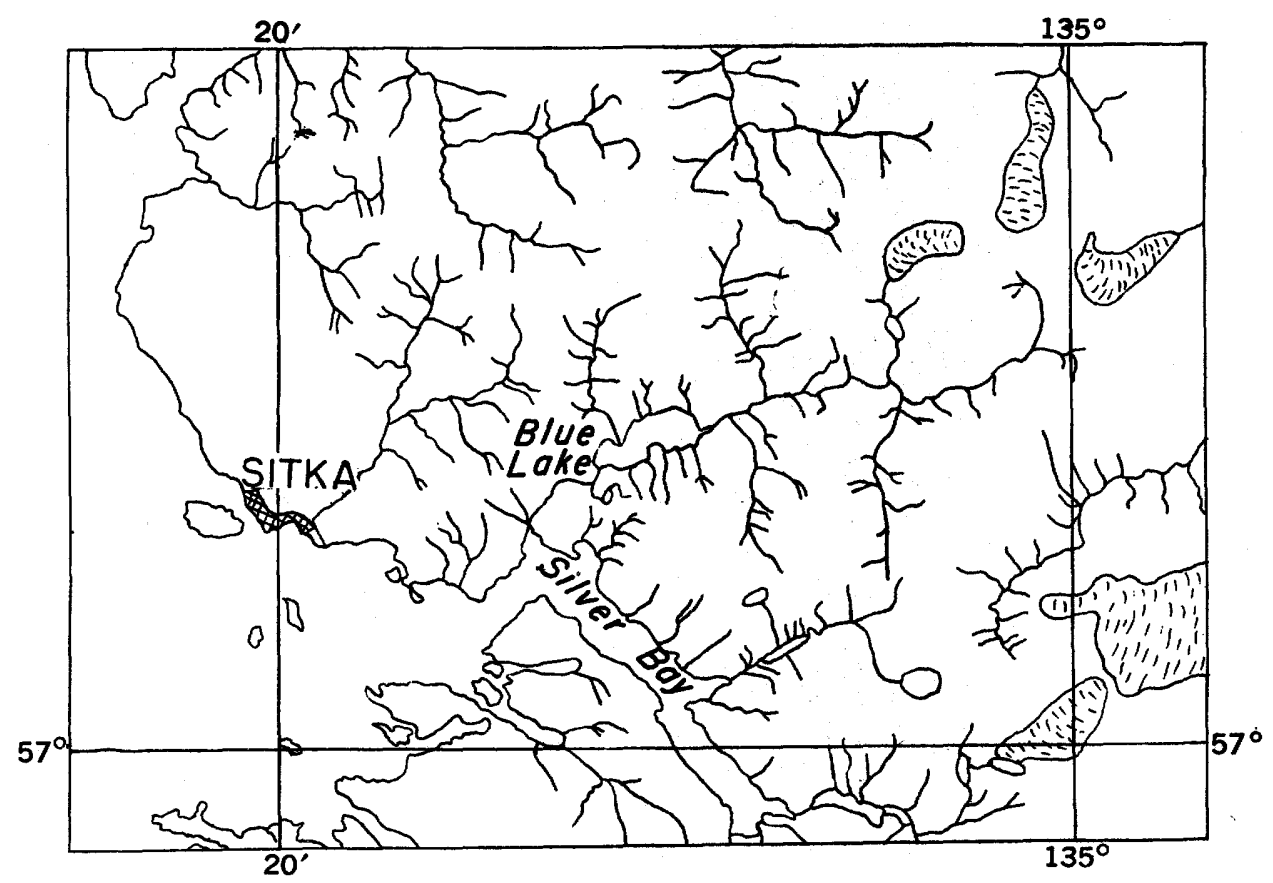

Figure 1. Index map showing location of Blue Lake. 
No evidence was found in the course of this investigation that supports either of these theories of origin. In the judgment of the writer, based on familiarity with the geology of southeastern Alaska, excavation of the pre-existing valley floor by a valley glacier is the most probable explanation of the origin.

The troughlike character of the valley, the round land forms, and the presence of freshly scoured bedrock surfaces all attest to glaciation within recent times. Blue Lake basin is similar to many other lake basins in glaciated areas, which were excavated by the glacial ice. The author's observations indicate that except for the present outlet the entire lake basin is bounded by bedrock to an elevation of $400 \mathrm{ft}$ or more. At no place near the southwest end of the lake were any deposits of glacial debris observed. A careful search was made because if such debris existed it might well be so permeable that it could cause leakage of a reservoir formed by the damming of Blue Lake outlet. The bedrock at the southwest end of Blue Lake is a metamorphic sequence af slate, argillite, and graywacke and should be fairly impermeable.

\section{Bedrock}

The rocks in this area trend about N. $60^{\circ}$ W. and dip from $70^{\circ}$ SW. to vertical. Knopf 1/ (1912, pp. 13-14) subdivided the rocks in the Sitka area into two large groups. The easternmost, which includes the area in the vicinity of Blue Lake, is largely greenstone and phyllite and is tentatively assigned to the Faleozoic on the basis of lithologic character. The western belt of rocks, which includes those in the vicinity of Sitka, is predominantly slate and graywacke and is assigned on the basis of lithology to the Mesozoic. The boundary between these two major subdivisions is shown on Knopf's map to pass approximately along the southwestern boundary of the greenstone shown on figure 2 of this report. These age assignments and boundaries are very questionable and should be so regarded until further work is done.

For this report four distinct units of rock are described (See fig. 2): conglomerate, slate, argillite, and graywacke; greenstone; and slate, argillite, and graywacke. All of these rocks strike uniformly northwest and either are vertical or dip steeply to the southwest. They are apparently conformable.

The conglomerate crops out in a band about $1,200-1,300 \mathrm{ft}$ wide along the northeast shore of Silver Bay from the mouth of the Medvetcha River to Herring Cove. It consists of well-rounded pebbles and cobbles, from $\frac{1}{2}$ to 6 inches in diameter, in a matrix of black argillite and slate. The -pebbles and cobbles consist of argillite, quartz, diorite, and andesite, all firmly cemented in the matrix. The rock is so highly metamorphosed that fractures extend through matrix and pebble alike without apparent deviation.
A band of rocks comprised of slate, argillite, and graywacke about $1,700 \mathrm{ft}$ thick borders the conglomerate band on the northeast. 'These rocks are massively bedded and dark-colored. They are metamorphosed to a hard, dense, fine-grained, brittle rock that is intricately fractured in such a manner that it breaks into small angular pieces ranging in size from a few inches to 10 or 12 inches across. These rocks are fairly solid when freshly exposed, but on exposure to the elements the incipient fractures in the rock give away and the rock is readily broken. Neither bedding nor cleavage planes are very prominent and are not planes of weakness as compared to the fracture system.

Northeast of the slate, argillite, and graywacke unit is a band of greenstone about $2,500 \mathrm{ft}$ thick. The greenstone is massive and without conspicuous fractures. It is mottled green and white, apparently consisting of a firmly intergrown mixture of amphibole and feldspar. It appears to represent metamorphosed lava flows and as such is a very firm and solid rock.

For an unknown extent, but for at least 7,000 $\mathrm{ft}$ to the northeast of the border of the greenstone, is another sequence of slate, argillite, and graywacke similar in all apparent respects to the slate, argillite, and graywacke sequence between the conglomerate and greenstone.

\section{DAM SITE}

It is generally considered that the best dam site is in the canyon immediately below the outlet of Blue Lake. (See fig. 2) Here the canyon walls extend steeply upward from river level for 200 to $250 \mathrm{ft}$ and a relatively small amount of material would be needed for dam construction. The canyon walls are stripped of all vegetation and loose rock, and the stream flows over bedrock. Very little stripping of material at the dam site would be necessary. The rock exposed is fresh argillite and slate, intensely fractured, but otherwise firm and solid. It is thought that removal of this fractured rock to a depth of 2 or $3 \mathrm{ft}$ would expose less fractured rock and would provide firm dam foundation and abutments. No faults were seen in the area of the dam site.

Both a gravity-type concrete dam and a concrete arch dam have been considered. The tendency of the bedrock to develop fractures upon exposure should be investigated in evaluating the suitability of the site for an arch dam.

Consideration should be given to spillway design and construction so that the overflow will not erode the rock adjacent to the toe of the dam. The slate and argillite is so fractured that it is readily susceptible to a quarrying effect by falling water.

Sand and gravel for concrete aggregate probably could be developed at the mouth of Stuart Creek where it empties into the eastern end of Blue 
Lake. Another possible source is the delta of the Medvetcha River. However, the delta is entirely below high tide level.

It should be noted that this area is in an earthquake zone, although not a particularly active one. The dam should be constructed to minimize possible earthquake damage.

\section{TUNNEL}

Froposals for the development of Blue Lake power include a tunnel at an altitude of about $200 \mathrm{ft}$ from Blue Lake to either Herring Cove or the mouth of the Medvetcha River. The former would be about $6,000 \mathrm{ft}$ long, the latter about 7,000 ft long. Either tunnel would encounter similar geologic conditions.
All of the rocks to be encountered in the tunnel can be expected to stand well for an indefinite period. However, in these rocks numerous faults, from a few inches to as much as 4 or $5 \mathrm{ft}$ wide, can be expected at intervals averaging about every 100 or $150 \mathrm{ft}$. The material in these faults will be soft and claylike and the tunnel walls may have to be lined at these places in order to prevent caving and consequent plugging of the tunnel.

The greenstone is a particularly solid rock and few faults or fractured zones will be encountered. Möre zones of weskness can be expected in the other rocks. It can be expected that the rocks throughout the tunnel are tight and will not leak any appreciable quantity of water. 


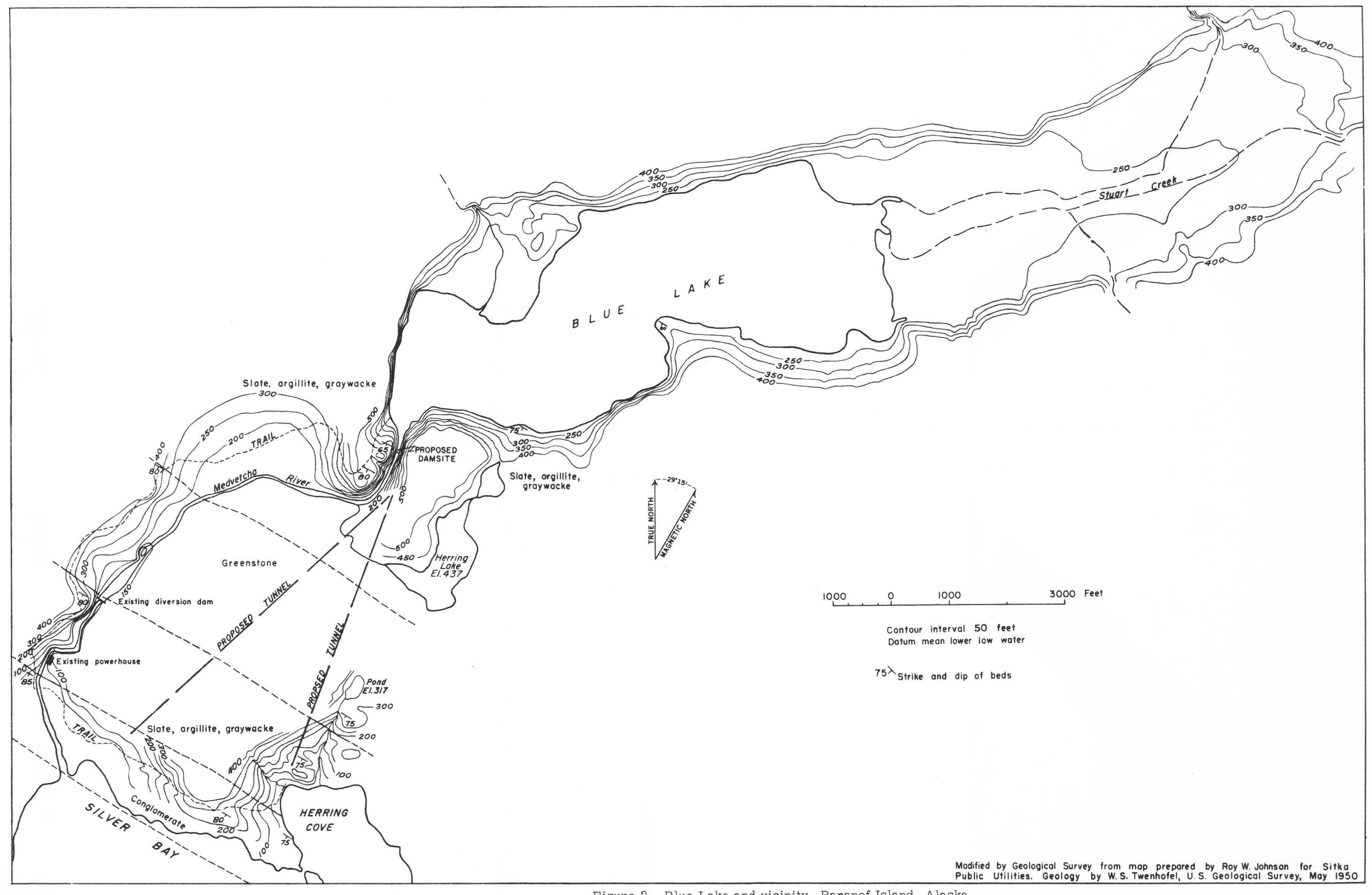

